

Journal of Education, Teaching and Learning is licensed under

A Creative Commons Attribution-Non Commercial 4.0 International License.

\title{
THE EFFECT OF INSTRUCTIONAL APPROACH AND VERBAL REASONING ON StUdents' SCIENTIFIC Writing AbILITY
}

\author{
Ratu Wardarita ${ }^{1)}$ \\ 1) Universitas PGRI Palembang, South Sumatera, Indonesia \\ E-mail: ratuwardarita@yahoo.com
}

\begin{abstract}
The objective of this research is to find out the difference between instructional approaches and verbal reasoning on students' scientific writing ability. It was conducted at Indonesian Language Study Program, Faculty of Teacher Training and Education, University of PGRI Palembang. This research employed the experimental method using 2x2 factorial Anova test, with 43 students chosen randomly through multi-stage sampling technique. The results of this research indicate that: (1) the group of students taught with the contextual teaching and learning (CTL) approach has better than taught with the conventional one; (2) the group of high-level verbal reasoning students taught with CTL approach has better than taught with the conventional one; (3) the group of low-level verbal reasoning students taught with the CTL approach has lower than taught with the conventional one; (4) there is an interaction effect between instructional approach and the level of verbal reasoning on students' scientific writing ability.
\end{abstract}

Keywords: CTL approach, Conventional approach, Scientific writing ability, Verbal reasoning

\section{INTRODUCTION}

The ability to write scientific writing must be possessed by those who take a deep focus on the academic world, such as lecturers, teachers, researchers, and students. We also have to confess that the ability to write scientific writing is not only for academic need. In modern life, like the heads of organizations in private sector and government are claimed to own good scientific writing ability. They are often asked to inform ideas, plans, or report in the form of an article. The scientific writing ability undoubtedly must also be owned by students. Students need to get involved with the writing activity to write a handout, a book report, a research report, a thesis.

The ability of scientific writing needs to be provided to all students of faculty of teacher training and education since they are prospected to be intellectual teachers. In the era of science and technology growing very fast, the ability to write scientific writing becomes the intellectual image of someone. Someone's intellectual can be measured by the number of his/her scientific writing.

Students of the Indonesian language study program of PGRI University who follow the scientific writing course are supported by writing a handout for their final assignment. Generally, they have not been able to organize their ideas, to compile logical, systematic, and critical ideas. This problem gives effect on the other subjects that the students also take. Based on researchers' observation in the teaching and learning process of the course, all students were only assigned to compile a handout for the final assignment. Also, the lecture was only about knowledge, theory, and memorizing. The lecturers seldom instructed students to practice scientific writing for insufficient time reason. Even when the time was adequate, the lecturers only assigned the students to compile a scientific writing, for example making scientific writing in the form of a handout with a theme "The Juvenile Delinquency and the Way to Overcome!". However, the assignment was given without any guidance and discussion. The lecturers more focused to reach the curriculum goals so that lecturing was less varied. This makes condition that students were less active and productive although theoretically, they have mastered writing techniques. From this observation, it is known that the lecturing takes more attention on reaching goals than its process. Such lecturing will be less meaningful.

Dealing with the problems above, this research does not only investigate about the learning approach but also correlate it with the verbal reasoning in the ability to write scientific writing for the second-semester students in Indonesian Language Study Program, the University of PGRI Palembang, Indonesia. 
Language is the main mean in delivering scientific thinking activity because it is used in all scientific reasoning processes and at the same time it is used as a means of communication to deliver the way of thinking [Suriasumantri, 2005]. A precise and a well-organized reasoning also needs the correct use of language. That way, the use of correct language will express the ability to reasoning. The reasoning which uses language as the main mean is called verbal reasoning.

A scientific writing can be evaluated based on three aspects: substance, methodologies, and language. These aspects are related to each other; support each other to create a good scientific writing. If one of the aspects is not good, hence the article will be less scientific [Ihsan, 2003].

Problems appear in the second-semester students of Indonesian Language Study Program, the University of PGRI Palembang on scientific writing needs to be checked immediately. The interview results between the students and researchers are as follows: (1) the students have not possessed the ability to write, they were confused about how to begin writing and did not want to get involved in the activity of scientific writing competition; (2) the lecturer seldom gave practice writing scientific writing individually because of limited time and felt worried that learning goal was not achieved; (3) the learning techniques conducted by lecturer were giving lecture, practice in classical form; (4) the assessment given by lecturers was only test; (5) the students' ability to write was quite low. These problems must meet solution, so that later the students can write scientific writing.

In the effort of overcoming the student's problems in scientific writing ability, hence the researcher did experimental research to all second-semester students, Indonesian Language Study Program, Faculty of Teacher Training and Education, University of PGRI Palembang. Thereby, the researcher applied contextual teaching and learning (CTL) approach to all second-semester students who followed Indonesian subject for Scientific Writing to be compared to the conventional approach on scientific writing ability. The formulation research problems are:

1. Are there any differences between the ability of scientific writing between students who learn with the contextual approach and the conventional approach?

2. Are there any differences between the ability of scientific writing of high-level verbal reasoning students who learn with the contextual approach and the conventional approach?

3. Are there any differences between the ability of scientific writing of low-level verbal reasoning students who learn with the contextual approach and the conventional approach?

4. Are there any interaction effects between the teachinglearning approach and verbal reasoning towards the scientific writing ability?

\section{THEORETICAL FRAMEWORK}

\section{A. Scientific Writing Ability}

Nystrand [1982] said student writing takes place in a context, and one thing writers need to learn is how to deal with it. The imbalance between students and teacher is aggravated by their not knowing how to code gestures and intonation in linguistic forms or how to successfully predict the response of their reader. The writer is usually much more conscious of 'what' to communicate than 'to whom' the writing is read.

Even outside the academic community, academic writing has distinct characteristics that set it apart from other types of language. There are six characteristics that are common to good academic or scientific writing: (1) significant, (2) clear, (3) unified and well organized, (4) economical, (5) adequately developed, (6) grammatically acceptable [Hairston, 1986].

Gagne and Briggs [1997] suggest that ability is the learning outcomes obtained by learners after attending a lesson. This term refers to the knowledge of writing skills and understanding of writing. According to Lado [1964], writing is composing board signs (graphic symbols) that expressed a language known by someone, so that others can read the signs written if they recognize and understand the language.

Writing requires thought, discipline, and concentration. Writing involves committing something to relatively permanent form. It is a record by which we are judged by whoever reads what we have written. Quite apart from matters such as handwriting, spelling, and grammar, our reader will also judge us by our style, content and logic of what we have written. So writing demands care and thought [White, 1983].

Based on the form, this scientific writing can be divided into (1) book, (2) paper (for journals, seminars, reports, etc.), (3) thesis, and (4) dissertation. The form of scientific writing intended in this research is the scientific papers, particularly papers tasks (research paper, term paper, or paper library).

Heaton [1998] said that rating scale in writing is the result of considerable and careful research conducted. The scoring consists of (1) content, score 30; (2) organization, score 20; (3) vocabulary, score 20; (4) language use, score 25; (5) mechanics, score 5.

A Scientific paper based on Hairston's [1986] opinions is reflecting an impartial author attempts to find the right answers and solutions that can be implemented (workable) for any questions or problems. Students can make a good scientific paper if they consider some specific situations. The criteria for good expository essay, according to Hairston (1986) include (1) meaningfulness, (2) clarity, (3) cohesion and good organization, (4) economics, (5) the adequate advance, and (6) the acceptability of grammar.

The effective topic paragraph must fulfil a number of requirements. McCrimmon [1986] mentions four conditions, namely (1) cohesion, (2) completeness, (3) the order of the logical sentence, (4) coherence. Finally, based on some of the points above, it can be formulated that students' ability 
to write scientific papers is their proficiency in composing an essay based on the facts, using the method of scientific writing, using a standard Indonesian language and follow the principle of enhanced Indonesian spelling and the rules of scientific writing.

The components of scientific writing ability are (1) the content, which includes the relevance, the explicitness of analysis, and the accuracy of the conclusions; (2) the organization of content, which includes cohesion, coherence, development of main ideas (paragraph and explanatory), and the overall organizational arrangements; (3) the grammar, which includes the formation of word accuracy and wellform of the sentence; (4) diction, which includes the use of the word accuracy with respect to the ideas presented, the appropriateness of using the word in context, (5) the spelling, which includes the use of letters, spelling, and usage of punctuation; and (6) scientific notation, including format of scientific writing, the writing of citation resources, and the writing of a bibliography.

\section{B. Contextual Teaching and Learning (CTL) Approach}

Learning would be more meaningful if the students "experience" what they learn, not only "know". The learning with material mastery oriented has proven to be successful in the ability of "remember" in short-term memory but fails to provide children in solving problems in long life [Depdiknas, 2002].

Similarly, in learning language, issues concerning the lack of success of language learning have been often mentioned by experts. Some research findings stated that many high school graduates are not able to make a job application letter. Sentences used are incoherent, illogical reasoning. When the interview was held, they cannot speak fluently and have less communicative language. Therefore, in anticipation for students to be able to skillfully speak, both spoken and written communication, it is required teaching and learning strategies that relate more to realworld situations.

Contextual teaching and learning (CTL) approach corresponds the learning to students' real-world situations, encourages students to link between the knowledge and its application in their lives as members of the family and society. With this learning concept, the learning outcomes are expected to be more meaningful. The contextual approach is a learning concept to assist teachers/lecturers to teach their students to relate knowledge they get in class with real-world situation. CTL approach involves seven main components of effective learning, namely: constructivism, questioning, inquiry, learning community, modelling, reflection, and authentic assessment. In other words, CTL is more concerned with the process than the result [Johnson, 2002].

\section{Conventional Approach}

The conventional approach is often referred to the traditional learning approaches or partial learning approach. According to Busching and Lundsteen [1983], the conventional approach is the learning which considers that any learning as a discipline. In primary education, reading, writing, arithmetic, geography, and history are taught. Each topic is separated from the aspects of language skills; listening is separated from speaking, as well as reading is separated from writing.

The conventional approach focuses on intellectual development through memorizing things that have been read and the tasks that have been done. Planning the learning and developing skills, social attitudes, and the appreciation receive less attention in the conventional approach. Teachers are often troubled with discipline problems; teachers give more punishment and force and act as an authoritarian. Measurement and evaluation of learners are intended only to determine aspects of the mastery of knowledge [Hamalik, 2005].

The main point of conventional learning by Fogarty [1991] is the separation between the fields of study and other subjects. This learning is separate as traditional ways in designing curriculum and learning materials. This assumption is learning between subjects/courses one and the other are different and fragmented.

The conventional approach in language is learning that considers language as a complexity that can be divided into separate segments such as phonemes, morphemes, and so on. Therefore, language is considered as the lesson given separately. The conventional approach has certain characteristics. namely: (1) not in context, (2) did not challenge, (3) passive, and (4) learning materials are not discussed with the learners [Wortham, 1996].

\section{Verbal Reasoning}

Language is an important factor to support the ability to think organized and systematically. The use of language as media of reasoning is needed by the scientific reasoning in selecting the words and also structure method. In other words, in scientific writing article with Indonesian language should be standard: correct and good. Correct language is language follows the determined method. Good language is a language using correct language manner based on the condition and situation. The standard language methods include several things like spelling method, punctuation, vocabulary, and structure. Besides, the language used also has to pay attention to logical; that sentence used has to mean and can be accepted by common sense.

An important component of thinking is the reasoning. Verbal reasoning is reasoning that uses language. D'Angelo [1980] stated that reasoning is drawing conclusions from observations, facts, or hypotheses. According to Leahey and Harris [1997], reasoning is the process of withdrawing logical conclusion based on the facts or existing premise.

The reasoning is logical and analytical thinking process. Logical thinking is the thinking according to a certain pattern, and certain logic thinking. Meanwhile, according to Leonard [1967] logic is the science of reasoning. The science of reasoning means trying to find and declare the rules in accordance with the thinking that can be considered good and bad, right or wrong, or makes sense or not. The same thing was stated by Copi [1978] that logic is the study of methods and principles used to distinguish correct 
reasoning from incorrect reasoning. Thus, it can be said that reasoning has its own logic.

Based on the explanation above, there are some important elements contained in reasoning: (1) facts (evidence), (2) analytic, (3) the goal (a conclusion in the form of knowledge), (4) logical (whether in relation to evidence of or conclusions). From these elements, it can be seen that reasoning is done consciously.

Language, logic, mathematics, and statistics are needed to perform activities of scientific thinking [1]. Among those means, language is the primary tool because it is used in all of the scientific reasoning process and also a communication tool to convey the thoughts to others. Reasoning coherently and precisely requires the use of appropriate language and vice versa, proper use of language reflects the reasoning abilities. Reasoning that uses language as a primary means is called verbal reasoning.

Reasoning as valid inferences process is divided into inductive reasoning and deductive reasoning [17]. According to D'Angelo [16], induction is contradictory reasoning in the special or specific leads to a general conclusion. Instead, the deduction is reasoning from the general to the specific to reach a conclusion.

Finally, it can be concluded that verbal reasoning is the ability to think or to draw conclusions that the truth can be accounted either inductive or deductive using language as the main means. The components which refer to verbal reasoning are (1) inductive conclusion, which includes the generalization, analogies, and the causal relationship or causation; (2) deductive conclusion, and (3) the avoidance of any reason

\section{RESEARCH METHOD}

This research is conducted at the Study Program of Indonesian Language, Faculty of Teacher Training and Education, University of PGRI Palembang, the second semester of academic year 20015/2016. This research uses an experimental method using $2 \times 2$ factorial designs, with 43 students chosen randomly through multi-stage sampling technique.

TABLE I

EXPERIMENTAL DESIGN 2X2

\begin{tabular}{|c|c|c|}
\hline \multirow{2}{*}{$\begin{array}{l}\text { Treatment } \\
\text { Variable }\end{array}$} & \multicolumn{2}{|c|}{ Instructional Approach (A) } \\
\hline & $\begin{array}{l}\text { Contextual } \\
\qquad\left(\mathrm{A}_{1}\right)\end{array}$ & $\begin{array}{c}\text { Conventional } \\
\qquad\left(\mathrm{A}_{2}\right)\end{array}$ \\
\hline Attribute & & \\
\hline Variable & & \\
\hline $\begin{array}{c}\text { Verbal } \\
\text { Reasoning }\end{array}$ & $\mathrm{A}_{1} \mathrm{~B}_{1}$ & $\mathrm{~A}_{2} \mathrm{~B}_{1}$ \\
\hline $\begin{array}{l}\text { Low } \\
\left(\mathrm{B}_{2}\right)\end{array}$ & $\mathrm{A}_{1} \mathrm{~B}_{2}$ & $\mathrm{~A}_{2} \mathrm{~B}_{2}$ \\
\hline
\end{tabular}

Notes:

Dependent Variable: Scientific Writing Ability

Independent Variable

- Treatment (A): Instructional Approach

\section{$\mathrm{A}_{1}$ : Contextual, $\mathrm{A}_{2}$ : Conventional}

- Attribute (B): Verbal Reasoning

$$
\mathrm{B}_{1} \text { : High, } \mathrm{B}_{2} \text { : Low }
$$

The multi-stage random sampling technique done was first by purposive sampling that is determining the secondsemester students of Indonesian Language Program Study, Faculty of Education, University of PGRI Palembang. The second, by random sampling, that is choosing 2 classes from 4 classes in the second-semester students with random technique (random) for the class of the conventional approach class and the contextual approach class. The two classes are about 86 students; each class consists of 43 experimental group students and 43 control group students tested by verbal reasoning. The score obtained from the test later is ranked, about $30 \%$ of the group own high verbal reasoning, while $30 \%$ of the group own low verbal reasoning. By that method, there are 13 students obtained as the sample for the high group and low group from each experimental group and control group.

The instruments used to take data in this research are as follows: (1) verbal reasoning test, (2) scientific writing test. The test instrument was tested to all samples to know whether the test developed is valid and reliable. Biserial point is used to determine the validity of verbal reasoning test; KR-20 formula is used to count its reliability. To know the reliability of test in writing scientific, the interrater reliability is used, high-reliability coefficient indicates the assessment of high inter-rater, and conversely, lowreliability coefficient indicates that inter-rater gives the different assessment.

The data collected is analyzed by using inferential statistics and descriptive statistics. The data obtained is described based on each variable. The technique to analyze in this research is analysis of variance (ANOVA). At the significant level $=0.05$ and $=0.01$. The analysis is continued with Tuckey test to know if there is a meaning of the interaction.

Normality test and population homogeneity test are done before data result of this research is analyzed statistically. Normality test which is used is Liliefors test, while homogeneity test uses Bartlett test, with significance level = 0.05 and $=0.01$.

\section{RESUlT OF STUDY}

Two-ways analysis of variance (ANOVA $2 \times 2$ ) is done to see the difference of treatment (to test the research hypothesis) (see table 2 and table 3 ). 

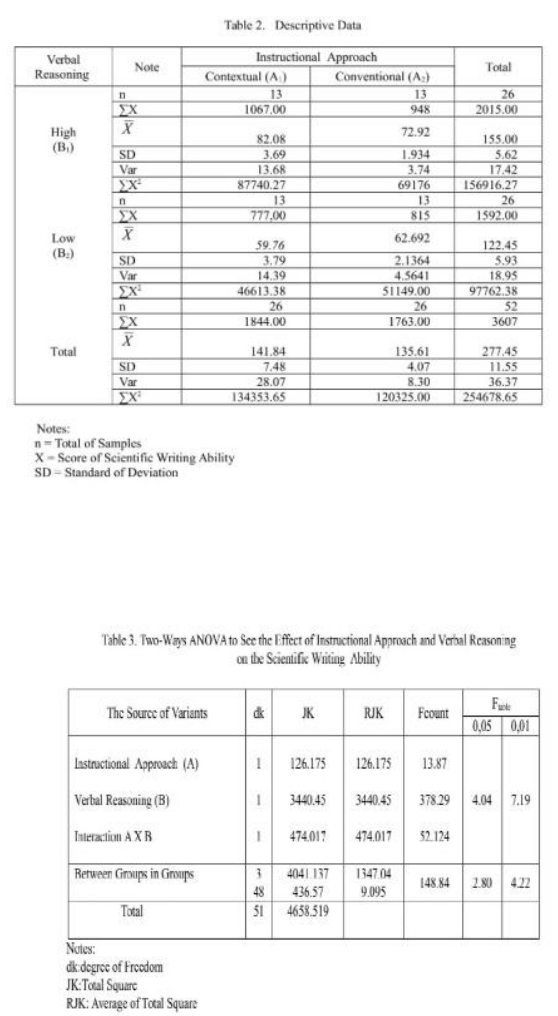

\section{Findings AND Discussion}

Based on the result of calculating two-ways ANOVA, it can be concluded as follows:

\section{A. The First Hypothesis}

There is the difference between the ability to write scientific writing among students who learn with the contextual approach with the conventional approach. Statistically, this hypothesis is formulated:

$\mathrm{H}_{0}: \mu \mathrm{A}_{1}=\mu \mathrm{A}_{2}$

$\mathrm{H}_{1}: \mu \mathrm{A}_{1}>\mu \mathrm{A}_{2}$

$\mu \mathrm{A}_{1}=$ mean score of the ability to write scientific writing for students who learn with the contextual approach.

$\mu \mathrm{A}_{2} \quad=$ mean score of the ability to write scientific writing for students who learn with the conventional approach.

Based on the ANOVA table, it is obtained by $F_{\text {count }}$ for the effect of columns approach of study equals to 378.29 is greater than $\mathrm{F}_{\text {table }}$ with significance level $=0.01 . \mathrm{F}_{\text {count }}=$ $378.29>\mathrm{F}_{\text {table }}=7.19$ directs to reject null hypothesis $(\mathrm{H} 0)$. This matter proves that there is the difference among students who learn with the contextual approach and who learn with the conventional approach.

\section{B. The Second Hypothesis}

There is the difference between the ability to write the scientific writing of high verbal reasoning students who learn with CTL and conventional approach. Statistically, this hypothesis is formulated:
Ho: $\mu A_{1} B_{1}=\mu A_{2} B_{1}$

$\mathrm{H}_{1}: \mu \mathrm{A}_{1} \mathrm{~B}_{1}>\mu \mathrm{A}_{2} \mathrm{~B}_{1}$

$\mu A_{1} B_{1}=$ mean score of the ability of high verbal reasoning students to write scientific writing who learn with the CTL approach.

$\mu A_{2} \quad B_{1}=$ mean score of the ability of high verbal reasoning students to write scientific writing who learn with the conventional approach.

Mean score for the student's ability to write scientific writing group who has the ability of high verbal learning with CTL approach equals to 82.08. Meanwhile, the ability to mean score write scientific writing for students group owning the ability of high verbal by using CTL approach study equals to 72.92 .

The comparison test for the two approaches is done by using Tuckey test. The result of comparison test proves that the ability to write scientific writing for students by using CTL approach for students group owning high verbal reasoning is better than the conventional. This matter is proved from the result of the empirical analysis shows the result of the form of Qcount $=10.95>$ Qtables of $=3.36$ with the level of significance $=0.05$. Based on the result of variant analysis and comparator test, Tuckey test, it can be concluded that the students with high verbal reasoning who learn with CTL approach have the ability to write better than with the conventional approach. The result of the test can be seen in table 3.

\section{The Third Hypothesis}

There is the difference for the ability of scientific writing of low-level verbal reasoning students who study by using the contextual approach and the conventional approach. Statistically, this hypothesis is formulated:

$\mathrm{H}_{0}: \mu \mathrm{A}_{1} \mathrm{~B}_{2}=\mu \mathrm{A}_{2} \mathrm{~B}_{2}$

$\mathrm{H}_{1}: \mu \mathrm{A}_{1} \mathrm{~B}_{2}<\mu \mathrm{A}_{2} \mathrm{~B}_{2}$

Mean score of the ability to write the scientific writing of low-verbal level of students who learn with CTL approach is 59.76. Meanwhile, mean score of the ability to write the scientific writing of low-verbal level of students who learn with the conventional approach is 62.69. Then, Tuckey test is tested to know which approach of study gives better result to write scientific writing. The result of Tuckey test shows that the ability of scientific writing of low-level verbal reasoning students who study by using the contextual approach is better than those who study with the conventional approach. The result is empirically proven that Qcount $=3.507>$ Qtable $=3.36$ with level of significance is (0.05).

\section{The Fourth Hypothesis}

There is interaction effects between the teaching-learning approach (contextual and conventional) and verbal reasoning (low and high) towards the scientific writing ability. Statistically, this hypothesis is formulated:

Ho: $\mu \mathrm{AxB}=0$

$\mathrm{H} 1: \mu \mathrm{AxB} \neq 0$ 
Based on the calculation of the ANOVA test, it can be seen that Fcount for the interaction factor is 52.124 is higher than Ftable $=7.19$ at level of significance 0.01. Thereby, Ho hypothesis is rejected. This shows that there is interaction effects between the teaching-learning approach (contextual and conventional) and verbal reasoning towards the scientific writing ability. The interaction between the learning approaches and verbal reasoning towards scientific writing ability of students is shown in figure 1 .

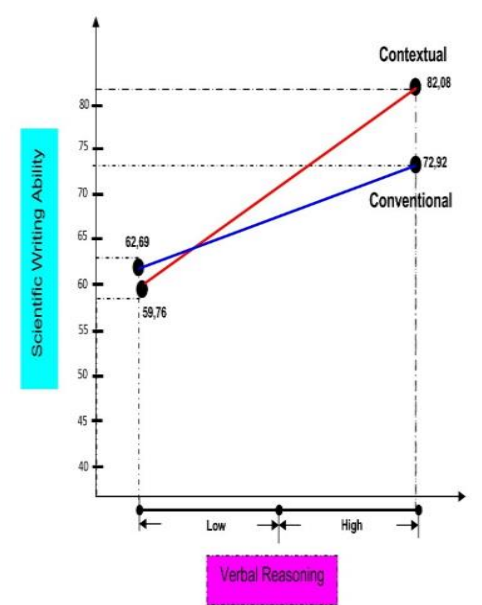

Figure 1: The Interaction between the Learning Approaches and Verbal Reasoning towards Scientific Writing Ability

From the Anova test that shows the interaction effect, post-hoc test is then tested. From the post-hoc test, it is obtained that $\mathrm{Qh}=23.18>\mathrm{Qt}=5.67$ in 0.01 significance level which means there is significant interaction effects between the teaching-learning approach (contextual and conventional) and verbal reasoning (low and high) towards the scientific writing ability. Accordingly, there is interaction between the ability of high-verbal reasoning students who learn with the contextual approach and the ability of low-verbal reasoning students who learn with the conventional approach to write scientific writing.

In conclusion, from the analysis of the fourth hypothesis, it can be seen that there is interaction between the learning approaches and student verbal reasoning towards the ability to write scientific writing in Study Program of Indonesian Language, Faculty of Teacher Training and Education, University of PGRI Palembang. Furthermore, the contextual approach is a better approach to increase and develop scientific writing ability of students especially high-verbal reasoning students. Meanwhile, for the students with lowverbal reasoning, it is better to learn with the conventional approach.

\section{CONCLUSIONS}

The paper will not be reformatted, so please strictly keep the instructions given above, otherwise it will be returned for improvement. Please upload your paper in PDF file through the Conference website under Paper Submission menu. Papers sent by e-mail will not be processed.
Based on the results of the hypothesis testing, generally this study proves that the ability to write scientific writing of students who learn with the contextual approach is better than the ability to write scientific writing of students who learn with conventional approach. Another point, the scientific writing ability of high-level verbal reasoning students who learn with the contextual approach is better than the scientific writing ability of students who learn with the conventional approach. On the contrary, the scientific writing ability of the low-verbal reasoning students is better when the students learn with the conventional approach. It can be seen from the interaction effects between the teaching-learning approach and verbal reasoning towards the scientific writing ability.

From the findings, it can also be concluded that the learning result of Indonesian language for scientific writing is influenced by learning approach and student verbal reasoning. Scientific writing learning with right learning approach will give better learning result. The contextual approach can be used for students with high verbal reasoning. Meanwhile, the conventional approach is suggested to be used for students with low verbal reasoning.

\section{REFERENCES}

Bushing, BA \& Lunsteen, SW. (1983). Curriculum Models for Integrating the Language Arts. Illinois: National Council of Teachers of English.

Copi, IM. (1978). Introduction to Logic (5th ed.). New York: McMillan Publishing Co.Inc.

D’Angelo, FJ. (1980). Process and Thought in Composition. Cambridge: Winthrop Publishers Inc.

Depdiknas. (2002). Pendekatan Kontekstual (Contextual Teaching and Learning). Jakarta: Depdiknas, Dirjen Pendidikan Dasar dan Menengah, Direktorat Pendidikan Lanjutan Pertama.

Fogarty, R. (1991). The Mindful School: How to Integrate the Curricula. New York: IRI/Skylight Publishing Inc.

Gagne, RM \& Leslie, JB. (1997). Principles of Instructional Design. New York: Holt, Rinehart, and Winston.

Hairston, M. (1986). Contemporary Composition, Short Edition. Boston: Houghton Mifflin Company

Hamalik, O. (2005). Kurikulum dan Pembelajaran. Jakarta: Bumi Aksara.

Heaton, JB. (1998). Writing English Language Tests. New York: Longman Inc.

Ihsan, D. (2003). "Penggunaan Kaidah Bahasa dalam Sebuah Karya Tulis Ilmiah". Lingua Jurnal Bahasa dan Sastra, 5(1):30.

Johnson, EB. (2002). Contextual Teaching and Learning. California: Corwin Press, Inc.

Lado, R. (1964). Language Teaching. New York: McGraw Hill, Inc.

Leahey, TH \& Richard, JH. (1997). Learning and Cognition (3rd ed.). Englewood Cliffs, New Jersey: PrenticeHall Inc. 
Leonard, HS. (1967). Principles of Reasoning: An Introduction to Logic, Methodology, and the Theory of Signs. New York: Dover Publication, Inc.

McCrimmon, JM. (1986). Writing with a Purpose (8th ed.). Boston: Houghton Mifflin Company.

Nystrand, M. (ed.) 1982. What Writers Know. London: Academic Press, Inc.

Suriasumantri, J. (2005). Filsafat Ilmu: Sebuah Pengantar Populer. Jakarta: Pustaka Sinar Harapan.
White, RV. (1983). Guidelines for Writing Activities A Magazine for Language Teachers. Singapore: Seameo Regional Language Centre.

Wortham, SC. (1996). The Integrated Classroom. New Jersey: Prentice Hall, Englewood Company. 